papers should, however, have been much more concise and conclusive, and it is unfortunate that discussions are lacking for Kirby's and McCracken's papers. There are a surprisingly large number of annoying typographical errors, and a brief index might facilitate the use of this volume for reference purposes.

B. D. Bavister

\section{INSECT PHYLOGENY}

\section{Die Stammesgeschichte der Insekten}

By Willi Hennig. Pp. 436. (Waldemar Kramer: Frankfurt am Main, 1969.) 38 DM.

Professor Hennrg, well known as a world authority on the insect order Diptera, and in the English-speaking world as the author of an important book on Phylogenetic Classification (1968), provides in this work the most comprehensive account of the phylogeny of insects yot to be published. The complexities and difficulties of the subject are such that a final and definitive account of it is unlikely to be written in the foreseeable future; Hennig himself admits that many of the ideas he advances are more or less speculative and liable to be disproved by future evidence. He bases his conclusions chiefly on the comparative anatomy of modern forms, interpreted in the light of Dollo's law and similar generalizations, and also on the fossil record, of which he gives a fairly lengthy review. The latter seems to be taken almost entirely from published sources and has the drawback that the fossils are seen only through the more or less theoryladen spectacles of the palaso-entomologists who have described them. The amount of attention given to the characters of immature stages is surprisingly small for the author of Die Larvenformen der Dipteren, and very little consideration is given to cytological, biochemical, physiological and serological data. Hennig would probably argue that the evidence from these non-morphological fields is as yet very scrappy, and that we have not enough data to be able to judge how far Dollo's law is applicable to such characters.

Hennig considers classical "adaptive radiations" to have been rare in the evolution of Insecta, most phyletic splittings having been simple dichotomies giving rise to pairs of "schwestergruppen". He takes the Insecta (= Hexapoda) and Myriapoda to stand in this relation to each other, and subsumes them in a higher division Tracheata; in contrast to S. M. Manton and her followers in Britain, he does not link the Tracheata with forms like Peripatus, but treats them as a "schwestergruppe" to Crustacea in a higher taxon Mandibulata. This idea receives some support from recent studies on enzymes, which Hennig does not quote. His reasons for rejecting a derivation of Tracheata from crustacean ancestors, and for postulating a separate Pre-Cambrian, presumably air breathing and terrestrial, ancestor for the insectmyriapod stock, do not convince me.

Within Insecta, Hennig makes a primary division of Entognatha and Ectognatha, and within the latter he separates the Machiloidea (Archaeognatha) from the remaining "Dicondylia"; the Dicondylia are split in turn into Zygentoma (Lepismatoidea) and Pterygota. These phylogenetic ideas are fairly widely accepted today, though many entomologists would hesitate to follow Hennig's logic in expressing them in a classification. He propounds what amounts to a new form of classification of insects, in which category names like subclass, order, suborder and tho like are not used. His cladistic taxa are indicated by numbers, the hierarchic level being inversely proportional to the number of digits (most $I$ 's and 2's) in the designation. 1 and 2 indicate Entognatha and Ectognatha respectively, 2.2 indicates Dicondylia, 2.2.2. Pterygota; the commonly recognized orders like Lepidoptera and Diptera are denoted by eight digits each. The system is logically coherent, as applied to modern forms, but would encounter difficulties if (as
Hennig does not do) the attempt were made to apply it to classifying fossils.

Particular interest, of course, attaches to Hennig's views on the phylogeny of Diptera. He rejects the view, held by Downes and others, that ancestral Diptera sucked vertebrate blood in favour of an original predaceous mode of life as in normal Mecoptera-and denies any direct relation of the order to Siphonaptera. Within Diptera he does not accept a primary Nematocera-Brachycera division, but first splits off a tipulid--trichocerid stock from the rest, which are then divided into a number of major stems, one of which is Brachycera (including Cyclorrhapha). His ideas might receive some support from the cytological work of M. J. D. White, which is not explicitly cited.

Speculatively inclined entomologists, whether or not they accept Honnig's conclusions, will find much to interest and stimulate them in this book. Even if it only provokes others into researches aimed at proving him wrong, Professor Hennig's work will have scrved a good scientific purpose.

R. A. Crowson

\section{NEUROENDOCRINE REGULATION}

Frontiers in Neuroendocrinology, 1969

Edited by William F. Ganong and Luciano Martini. Pp. xii +442 . (Oxford University Press: London and New York, October 1969.) 150s.

THIs book is the first of a projected series of biennial volumes surveying the frontiers of the new and expanding science of neuroendocrinology. This first volume, which surveys many areas of neuroendocrinology, is compiled by experts in their fields who include not only published data but, where pertinent, the results of their own current research as well. Each of the elevon chapters ends with an excellent bibliography to stimulate further reading.

The book begins with a chapter on the "Fine Structure of the Median Eminence and its Functional Significance". This chapter provides some excellent comparative aspects but unfortunately includes some rather controversial quantitativo data, emphasizing the need for more thorough quantitative assessment. The chapter on "Catecholamines in the Hypothalamus and the Pituitary Gland" is very interesting but poses more questions than it answers. The fact that the authors state that the noradrenaline afferent input to the hypothalamus seems to participate in neuroendocrino regulation still means that the exact role of the noradrenaline neurones remains to be determined. The chapter on "Short Feedback Mechanisms in the Control of Anterior Pituitary Function" suggests that all the hormones manufactured by both tho anterior and posterior lobes of the pituitary gland are capable of affecting their own rate of secrotion through short feedback mechanisms. Unfortunately much more work is required in this field. The hypothesis that short feedback mechanisms play a more general part than long feedback mechanisms is put forward. A study of possible interplay of short and long feedback systems during the major neuroendocrine events of puberty, ovulation and pregnancy suggested by the authors of this chapter is very important and certainly needs to be carried out.

The article on "Feedback Control of Gonadotrophin Secretion" is excellent. I belicve the author has come to a very valuable conclusion when he states that better and more precise physiological roles of the feedback mechanisms for the control of gonadotrophin secretion may be found if the new methods of gonadotrophin radioimmunoassay and steroid analysis are applied to the measurement of plasma steroid and gonadotrophin levels.

The last chapter, on the "Mechanism of Action of Releasing Factors", discusses fully the involvement of cyclic AMP in the release of the various pituitary hormones. 